\title{
Oral candidiasis and nutritional deficiencies in elderly hospitalised patients
}

\author{
Elena Paillaud ${ }^{1}$, Isabelle Merlier ${ }^{1}$, Catherine Dupeyron ${ }^{2}$, Elisabeth Scherman ${ }^{2}$, Joël Poupon ${ }^{3}$ and \\ Phuong-Nhi Bories ${ }^{2,4} *$ \\ ${ }^{1}$ Departement de Médecine Interne et Gériatrie, Hôpital Albert Chenevier, AP-HP, 40 rue Mesly, 94010 Creteil Cedex, \\ France \\ ${ }^{2}$ Laboratoire de Biologie, Hôpital Albert Chenevier, 40 rue Mesly, 94010 Creteil Cedex, France \\ ${ }^{3}$ Laboratoire de Biochimie-Toxicologie, Hôpital Fernand Widal, AP-HP, Paris, France \\ ${ }^{4}$ Laboratoire de Biochimie, Hôpital Hôtel-Dieu, AP-HP, Paris, France
}

(Received 14 February 2004 - Revised 25 June 2004 - Accepted 26 July 2004)

\begin{abstract}
The prevalence of oral candidiasis and its association with malnutrition in terms of protein-energy malnutrition and mineral and vitamin depletion were evaluated in ninety-seven hospitalised older adults aged 82.1 (SD 8.6) years. Patients underwent a complete oral examination with microbiological investigation on admission to our geriatric rehabilitation unit. Patients were assessed nutritionally by evaluation of dietary intake and measurement of anthropometric variables, serum nutritional proteins, ferritin, $\mathrm{Zn}$, folate, vitamins $\mathrm{B}_{12}$ and $\mathrm{C}$. The prevalence of oral candidiasis was $37 \%(n 36)$; the proportion of patients with BMI $<20 \mathrm{~kg} / \mathrm{m}^{2}$ was $32 \%$ ( $n$ 31). The nutritional status of the population was studied by comparing two groups defined according to the absence (group I; $n$ 61) or presence (group II; $n$ 36) of oral candidiasis. The two groups did not differ on the basis of BMI and mid-arm circumference. However, group II had a smaller leg circumference, lower daily energy and protein intakes, lower albumin and transthyretin levels. Patients successfully treated with fluconazole increased their intake on day 30 . The proportion of patients with hypozincaemia $(<12.5 \mu \mathrm{mol} / \mathrm{l})$ and vitamin $\mathrm{C}$ deficiency $(<0.7 \mathrm{mg} / \mathrm{l})$ was higher in group II. Treatment with antibiotics, poor oral hygiene, denture wearing, and vitamin $\mathrm{C}$ deficiency appeared as the most significant independent risk factors associated with oral candidiasis. The present findings show that oral candidiasis appears to be related to malnutrition and results in mucosal lesions that have a negative impact on energy intake, which may subsequently worsen nutritional status.
\end{abstract}

Malnutrition: Oral candidiasis: Elderly: Vitamin deficiency

Undernutrition in frail older individuals is frequent; $30-$ $60 \%$ of geriatric patients in intermediate- or long-stay wards are malnourished. Malnutrition in the elderly is a multifactorial problem involving physical, physiological, psychosocial and economic factors (Rudman \& Feller, 1989; Blaum et al. 1995). Predisposing factors include poverty, disability, inadequate nutritional support during illnesses such as depression, dementia, hip fractures, stroke, infectious and cancer diseases, and inappropriate use of restricted diets and drugs (Abbasi \& Rudman, 1993; Morley \& Kraenzle, 1994). Poor oral status has been frequently linked with malnutrition (Lamy et al. 1999; Sheiham, 2001). Oral health problems are important in old individuals and are characterised by the loss of teeth, impaired masticatory function, oral dryness, periodontal disease, caries and painful mucosal disorders (Samaranayake et al. 1995; Appollonio et al. 1997; Mojon et al. 1999).

Lesions of the oral mucosa are frequently caused by infection with the fungus Candida albicans. The prevalence of oral candidiasis ranges from 34 to $51 \%$ in geriatric in-patients (Rothan-Tondeur et al. 2001). Clinical diagnosis is made difficult by the wide range of mucosal signs resulting from this infection. Acute or sub-acute oropharyngeal candidiasis includes erythematous or pseudomembranous stomatitis. Chronic oropharyngeal candidiasis is associated with focal glossitis, uvulitis and perleche.

Factors that predispose patients to develop oral candidiasis include old age itself, denture wearing, poor dental hygiene, diabetes mellitus, xerostomia, and treatment with antibiotics and corticosteroids (Peterson, 1992; Shay et al. 1997). Altered immunological states, such as that seen in patients with HIV, render an individual extremely susceptible to colonisation and the development of oropharyngeal candidiasis (Lode \& Hoffken, 1989; Samaranayake, 1992). A possible mechanism may be a deficiency in cell-mediated immunity (Challacombe, 1994; Fidel, 2002). On the other hand, immune function is known to decline with age and protein-energy malnutrition (Miller, 1996; Lesourd \&

\footnotetext{
Abbreviations: CRP, C-reactive protein; LC, leg circumference.

* Corresponding author: Dr Phuong Nhi Bories, fax + 331498131 19, email phuong-nhi.bories@ach.ap-hop-paris.fr
} 
Mazari, 1999). However, relatively little attention has been paid to the nutritional factors which may be involved in the pathogenesis of oral fungal diseases. A few studies have investigated factors, such as $\mathrm{Fe}$, folic acid, vitamins $\mathrm{A}, \mathrm{B}, \mathrm{C}$ and $\mathrm{K}, \mathrm{Zn}$, malnutrition, and carbohydraterich diets, and suggested a possible role of these factors by means of alteration of the oral mucosa integrity (Samaranayake, 1986). Nevertheless, a consensus has not been reached.

Therefore, the present study was designed to determinate the prevalence of oral candidiasis in elderly in-patients and to evaluate its association with malnutrition in terms of protein-energy malnutrition and micronutrient depletion.

\section{Methods \\ Patients}

Ninety-seven patients aged 70 years or older (twenty-two males and seventy-five females, mean age 82.1 (SD 8.6) years), consecutively admitted to the Albert Chenevier Hospital (Creteil) between November 2001 and October 2002, were enrolled. These patients had been transferred from acute medical ( $n$ 52) or orthopaedic ( $n$ 45) units of other hospitals. The most frequent medical diagnoses were pulmonary disease, urinary-tract infection, congestive heart failure and cerebral vascular accident. Orthopaedic surgery was due to hip fracture. They were hospitalised in our twenty-bed geriatric rehabilitation unit of the Department of Internal Medicine. A multidisciplinary geriatric team provided care for patients in this unit; the unit geriatrician, two medical fellows, rehabilitation nurses, physical therapists, a social worker, and a dietitian. Patients included in the present study were medically stable and required long-term care and rehabilitation. Near-terminal medical disorders (for example, advanced malignancy, heart or pulmonary failure resistant to medical management) precluded participation in the study. The main criterion for hospital discharge was the recovery of walking self-sufficiency. Patients were informed of the purpose of the study in writing and gave their oral consent. The study design and procedures were in accordance with the recommendation of the hospital ethics committee.

\section{Study design}

A standardised questionnaire was used on admission to our unit (day 0) for recording age, sex, detailed information on past medical history, drug therapy, and cognitive and performance status using, respectively, the mini-mental state method of Folstein et al. (1975) and the standard Eastern Cooperative Oncology Group criteria (Dewys et al. 1980). In addition, a complete oral examination with microbiological investigation was made on day 0 and 1 month later (day 30). Patients were nutritionally assessed on day 0 by measurement of anthropometric variables and evaluation of dietary intake. A blood sample was collected after an overnight fast on the same day as the nutritional assessment for the determination of serum proteins and mineral and vitamin status.

\section{Anthropometric measurements}

Body weight, height and BMI (weight/height ${ }^{2}$ ) were recorded. Mid-arm circumference, leg circumference (LC) and triceps skinfold thickness were measured. Triceps skinfold thickness was measured by the same operator to the nearest mm using a Harpenden calliper and the average of three consecutive measurements was calculated.

\section{Dietary intake}

The patients received the usual diet given in hospitals of the Assistance Publique-Hopitaux de Paris, supplying on average $9.2 \mathrm{MJ} / \mathrm{d}$ with proportions of carbohydrate, lipid and protein of 55, 30 and $15 \%$ energy respectively. The diet was conventional; nutrients and fluids were given orally. The same dietitian recorded the energy and protein intakes immediately after each meal by estimation of portion sizes. Data acquisition was made $(\mathrm{g})$ and daily nutritional consumption was quantified by the CIQUAL database from Mac 2 Win software 1990-2000 (Altura Software Inc., Monterey, CA, USA). Data were obtained from $3 \mathrm{~d}$ food records. Energy needs were calculated for each patient according to the Harris-Benedict equation plus a stress factor of 1.2 (Roza \& Shizgal, 1984).

\section{Assessment of oral examination}

The clinical symptoms of oral discomfort assessed were: loss or distortion of taste; pain and soreness. The clinical signs of oral candidiasis were noted: leucoplakia; white plaques; red smooth mucosa; smooth tongue; angular cheilitis. Oral hygiene was considered as poor in the presence of: food debris; stains on or around the teeth and gingiva; tooth abrasions; fractured teeth or root tips. The presence of lower and/or upper dentures was noted.

\section{Biological measurements}

Serum C-reactive protein (CRP), and orosomucoid and transthyretin concentrations were analysed immunoturbidimetrically on a Synchron CX5 analyser (Beckman-Coulter, Roissy, France). Serum albumin was measured by means of the bromocresol green method with the Synchron CX5 analyser. Serum ferritin, vitamin $B_{12}$, and folate were measured by enzyme immunoassay with the Axsym analyser (Abbott, Rungis, France). Serum vitamin C was analysed after stabilisation and extraction with metaphosphoric acid solution, by HPLC with fluorometric detection. The limit of detection was $0.7 \mathrm{mg} / \mathrm{l}$ (Fain et al. 2003). After blood was sampled in heparinised tubes (Trace Element Vacutainer ${ }^{\circledR}$ Royal blue stopper; Becton Dickinson, Rungis, France), serum Zn was analysed by flame atomic absorption spectrometry with the AA 1100 analyser (Varian, Les Ulis, France).

\section{Microbiologic investigations}

Yeast research was performed by direct examination and culture. Identification was performed using the ID32C identification system for yeasts from bioMerieux s.a. (Marcy l'Etoile, France). At least three sites were sampled 
for each patient with cotton wool swabs, including the tongue, palate and buccal mucosa or lip commissures in the presence of angular cheilitis. The swabs, which were inoculated onto Sabouraud's dextrose agar, were incubated aerobically at $37^{\circ} \mathrm{C}$ for $2 \mathrm{~d}$, after which the plates were examined. The diagnosis of oral infection with Candida was established when patients exhibited oral symptoms of candidiasis and had positive culture results.

\section{Statistical analysis}

Statistical analysis was performed using the Statview statistical software package (version 5.0; SAS Institute Inc., Cary, NC, USA). The results are expressed as means and standard deviations. Differences in means between the two groups (see later) were analysed by the unpaired Student's $t$ test. Differences between non-continuous variables and percentages were tested by $\chi^{2}$ analysis. One-way ANOVA with repeated measures was used to study changes in energy intake over time. Correlations between two variables were calculated with least squares regression analysis. Logistic regression was used to identify the significant independent factors associated with the diagnosis of oral candidiasis. A $5 \%$ significance level was used in all comparisons.

\section{Results}

The evaluation of oral health problems in our patients is presented in Table 1 . In those with fungal disease, $C$. albicans was the most common species present and was isolated from twenty-four $(66.6 \%)$ positive culture samples. In six $(16.6 \%)$ patients, more than one Candida was isolated, the most common combination being $C$. albicans and $C$. glabrata $(n 5 ; 13.8 \%)$ followed by $C$. albicans and $C$. tropicalis ( $n 1 ; 2.7 \%)$. C. guillermondii, C. tropicalis and Candida species were also isolated in few patients, in the same proportion of samples $(n 2 ; 5.6 \%)$. The patients were treated with fluconazole. We were able to monitor the efficacy of this treatment in twenty-three patients 1 month later. Only twelve patients recovered from the candidal disease.

The nutritional status of the population was studied by comparing two groups defined on the basis of the absence (group I; $n$ 61) or presence (group II; $n$ 36) of oral candidal

Table 1. Frequency of oral health problems in the study population

\begin{tabular}{lrr}
\hline & $n$ & $\%$ \\
\hline Oral symptoms & 23 & 24 \\
Distortion of taste & 7 & 7 \\
Burning sensation & 11 & 11 \\
Soreness & 13 & 13 \\
Signs of oral candidiasis & 36 & 37 \\
Leucoplakia & 1 & 1 \\
White plaques & 26 & 27 \\
Red smooth mucosa & 4 & 4 \\
Smooth tongue & 15 & 15 \\
Angular cheilitis & 5 & 5 \\
Poor oral hygiene & 35 & 36 \\
Lower and/or upper dentures & 49 & 51 \\
\hline
\end{tabular}

infection. Anthropometric values were lower in group II (Table 2), although this was only statistically significant for LC $(P=0.033)$. The proportion of patients with BMI $<20 \mathrm{~kg} / \mathrm{m}^{2}$ was $32 \%$ in the whole population $(28 \%$ in group I and $39 \%$ in group II; odds ratio 1.6; $95 \%$ CI $0.7,3.9)$. Patients from the latter group had lower daily energy and protein intakes $(P=0.02$ and $P=0.05$, respectively; Table 2 ). The percentage of patients with an energy intake below their needs, as estimated by the Harris-Benedict equation, tended to be higher in this group (odds ratio $1.9 ; 95 \%$ CI $0 \cdot 8,4 \cdot 7$ ). Patients successfully treated with fluconazole increased their intake on day $30(6.0$ (SD 1.5) v. 7.5 (SD 2.5) $\mathrm{MJ} / \mathrm{d} ; \quad P=0.027)$ whereas those who still had oral candidiasis on day 30 did not change their intake (6.5 (SD 2.2) v. 6.1 (SD 2.1) $\mathrm{MJ} / \mathrm{d} ; P=0.524)$.

As far as biological data were concerned (Table 3), albumin and transthyretin levels differed significantly between the two groups $(P=0.002$ for both variables $)$, patients with oral candidiasis having mean protein levels at the lower limit of the reference values (albumin, 35-48 g/l; transthyretin, $0 \cdot 20-0.38 \mathrm{~g} / \mathrm{l})$. Orosomucoid and CRP levels were in the same range in the two groups and were above the reference range (CRP, $\leq 6 \mathrm{mg} / \mathrm{l}$; orosomucoid, $0 \cdot 4-1 \cdot 0 \mathrm{~g} / \mathrm{l})$.

The prevalence of mineral and vitamin depletion is presented in Table 4. Data from patients who had received mineral and/or vitamin supplements before admission into our department were excluded from the statistical analysis. The proportion of patients with hypozincaemia $(<12.5 \mu \mathrm{mol} / \mathrm{l})$ (reference interval $12.5-18.5 \mu \mathrm{mol} / \mathrm{l})$ and hypovitaminosis $\mathrm{C}$, defined as $<5 \mathrm{mg} / \mathrm{l}$ with a reference interval for healthy French men and women of $5-15 \mathrm{mg} /$ 1, was higher in group II although it reached statistical significance for $\mathrm{Zn}$ only. However, the proportion of patients with vitamin $C$ deficiency, defined as $<0.7 \mathrm{mg} / \mathrm{l}$ which was below the limit of detection of the method $(n 10)$ was higher in patients with candidiasis (57 v. 29\%; $P=0.025$; odds ratio $4 \cdot 6$; $95 \%$ CI 1.1, 19.1).

Finally, other factors that might be associated with oral candidiasis were studied (Table 5). Group II was significantly older than group I $(P<0.033)$. There was no difference in performance status and mental state among the groups. The proportion of patients suffering from diabetes was similar in the two groups, while that of patients who had been treated with antibiotics for $\geq 5 \mathrm{~d}$ within 1 month before admission to our department was dramatically higher in group II $(P<0 \cdot 001)$. The percentages of patients wearing dentures and with poor oral hygiene were also higher in this group ( $P=0.043$ and $P<0.001$, respectively).

The variables that were associated with oral candidiasis by unifactorial analyses were tested by multivariate analysis (Table 6). Treatment with antibiotics, poor oral hygiene, denture wearing, and vitamin deficiency were independent determinant risk factors. Age and albumin were weak risk factors and were interrelated $(r 0.375$; $P<0.002)$. LC and $\mathrm{Zn}$ depletion were not significant independent risk factors. Albumin, transthyretin and vitamin $\mathrm{C}$ levels correlated positively with total energy intake $(r$ $0.424, P<0.001 ; r 0.414, P<0.001 ; r 0.326, P=0.002$, respectively). $\mathrm{Zn}$ levels correlated positively with protein 
Table 2. Anthropometric variables and energy intake in patients without $(n 61)$ and with $(n 36)$ oral candidiasis (Mean values and standard deviations)

\begin{tabular}{|c|c|c|c|c|c|}
\hline & \multicolumn{2}{|c|}{$\begin{array}{l}\text { Without oral } \\
\text { candidiasis }\end{array}$} & \multicolumn{2}{|c|}{$\begin{array}{l}\text { With oral } \\
\text { candidiasis }\end{array}$} & \multirow{2}{*}{$\begin{array}{c}\text { Statistical } \\
\text { significance }(P)^{*}\end{array}$} \\
\hline & Mean & SD & Mean & SD & \\
\hline Weight (kg) & $60 \cdot 6$ & $16 \cdot 4$ & $56 \cdot 8$ & $13 \cdot 3$ & 0.246 \\
\hline BMI $\left(\mathrm{kg} / \mathrm{m}^{2}\right)$ & 23.3 & 5.5 & $22 \cdot 8$ & 4.8 & 0.618 \\
\hline $\mathrm{MAC}(\mathrm{mm})$ & 274 & 45 & 262 & 43 & 0.235 \\
\hline $\mathrm{LC}(\mathrm{mm})$ & 327 & 42 & 308 & 36 & 0.033 \\
\hline TST (mm) & 10.5 & 5.9 & $10 \cdot 8$ & 4.9 & 0.827 \\
\hline Energy intake $(\mathrm{MJ} / \mathrm{d})$ & 6.9 & 1.9 & 5.9 & 1.9 & 0.020 \\
\hline Intake < energy needs† (\%) & \multicolumn{2}{|c|}{$26 \cdot 7$} & \multicolumn{2}{|c|}{$41 \cdot 2$} & 0.147 \\
\hline Protein $(\mathrm{g} / \mathrm{d})$ & $60 \cdot 6$ & $17 \cdot 1$ & $52 \cdot 8$ & $20 \cdot 3$ & 0.050 \\
\hline Protein $<1.5 \mathrm{~g} / \mathrm{kg}$ per $\mathrm{d}(\%)$ & \multicolumn{2}{|c|}{93.2} & \multicolumn{2}{|c|}{$94 \cdot 1$} & 0.865 \\
\hline Carbohydrate (g/d) & 204.8 & $65 \cdot 3$ & 177.4 & 65.4 & 0.059 \\
\hline
\end{tabular}

MAC, mid-arm circumference; LC, leg circumference; TST, triceps skinfold thickness.

* Means between groups were compared using the unpaired Student's $t$ test; percentages between two groups were compared using the $\chi^{2}$ analysis.

$\dagger$ Estimate of energy needs according to the Harris-Benedict equation plus a 1.2 stress factor (Roza \& Shizgal, 1984).

Table 3. Serum proteins in patients without ( $n$ 61) and with $(n 36)$ oral candidiasis (Mean values and standard deviations)

\begin{tabular}{|c|c|c|c|c|c|}
\hline & \multicolumn{2}{|c|}{$\begin{array}{l}\text { Without oral } \\
\text { candidiasis }\end{array}$} & \multicolumn{2}{|c|}{$\begin{array}{l}\text { With oral } \\
\text { candidiasis }\end{array}$} & \multirow{2}{*}{$\begin{array}{c}\text { Statistical } \\
\text { significance }(P)^{\star}\end{array}$} \\
\hline & Mean & SD & Mean & SD & \\
\hline Albumin $(\mathrm{g} / \mathrm{l})$ & 37.4 & 4.1 & 34.4 & $5 \cdot 0$ & 0.002 \\
\hline Transthyretin (g/l) & 0.27 & 0.08 & 0.22 & 0.08 & 0.002 \\
\hline C-reactive protein $(\mathrm{mg} / \mathrm{l})$ & 26 & 47 & 40 & 52 & 0.175 \\
\hline Orosomucoid $(\mathrm{g} / \mathrm{l})$ & 1.47 & 0.44 & 1.51 & 0.46 & 0.660 \\
\hline
\end{tabular}

${ }^{\star}$ Means between groups were compared using the unpaired Student's $t$ test.

intake ( $r \quad 0.243 ; \quad P<0.019)$, orosomucoid ( $r \quad 0.265$; $P=0.009)$ and CRP levels $(r 0.355 ; P<0.001)$.

\section{Discussion}

In the present study, the prevalence of oral candidiasis in our patients was $37 \%$ and was comparable with results observed from similar studies in Swedish nursing homes (Palmqvist et al. 1984) and Scottish institutions (Schou et al. 1987) where the disease prevalence was 41 and $34 \%$ respectively. Wilkieson et al. (1991), using the imprint culture technique, reported a slightly higher rate $(47 \%)$ in the elderly in long-term hospital care. On the other hand, only two-thirds of our patients complained of oral symptoms. This was also observed by Brocker et al. (2000) who found that $64 \%(n$ 1256) of the patients having oropharyngeal candidiasis did not complain of symptoms suggesting the diagnosis. Therefore, the absence of reports of symptoms by older individuals emphasises the importance of frequent oral examinations and biological investigations, when necessary, since all these studies underline the high rate of candidal colonisation of the oral mucosa in institutionalised older individuals.

The main objective of the present study was to evaluate the association of malnutrition with oral candidiasis.

Table 4. Prevalence of mineral and vitamin depletion in patients without $(n 61)$ and with $(n 36)$ oral candidiasis

\begin{tabular}{|c|c|c|c|c|c|c|c|c|c|}
\hline & \multicolumn{2}{|c|}{ All patients } & \multicolumn{2}{|c|}{$\begin{array}{c}\text { Without } \\
\text { candidiasis }\end{array}$} & \multicolumn{2}{|c|}{$\begin{array}{c}\text { With } \\
\text { candidiasis }\end{array}$} & \multirow[b]{2}{*}{ OR } & \multirow[b]{2}{*}{$95 \% \mathrm{Cl}$} & \multirow{2}{*}{$\begin{array}{c}\text { Statistical } \\
\text { significance }(P) \dagger\end{array}$} \\
\hline & $n$ & $\%$ & $n$ & $\%$ & $n$ & $\%$ & & & \\
\hline Ferritin $<40 \mu \mathrm{g} / \mathrm{l}$ & $7 / 77$ & 9 & $12 / 49$ & 24 & $4 / 30$ & 13 & 0.5 & $0.1,1.6$ & 0.231 \\
\hline $\mathrm{Zn}<12.5 \mu \mathrm{mol} / /$ & $30 / 96$ & 31 & $14 / 60$ & 23 & $16 / 36$ & 44 & $2 \cdot 6$ & $1 \cdot 1,6 \cdot 4$ & 0.031 \\
\hline Folate $<4.0 \mu \mathrm{g} / \mathrm{l}$ & $11 / 77$ & 14 & $6 / 47$ & 13 & $5 / 30$ & 17 & 1.4 & $0.4,4.9$ & 0.633 \\
\hline Vitamin $B_{12}<200 \mathrm{ng} / \mathrm{l}$ & $7 / 94$ & 7 & $4 / 59$ & 7 & $3 / 35$ & 9 & $1 \cdot 3$ & $0 \cdot 3,6 \cdot 1$ & 0.749 \\
\hline Vitamin $\mathrm{C}<5 \mathrm{mg} / \mathrm{l}$ & $65 / 96$ & 68 & $37 / 60$ & 62 & $28 / 36$ & 78 & $2 \cdot 2$ & $0 \cdot 8,5 \cdot 6$ & $0 \cdot 102$ \\
\hline
\end{tabular}

OR, odds ratio.

* Data of patients who were supplemented were excluded from the statistical analysis.

† Comparison of proportions between groups using the $\chi^{2}$ analysis. 
Table 5. Association of clinical characteristics with oral candidiasis

(Mean values and standard deviations)

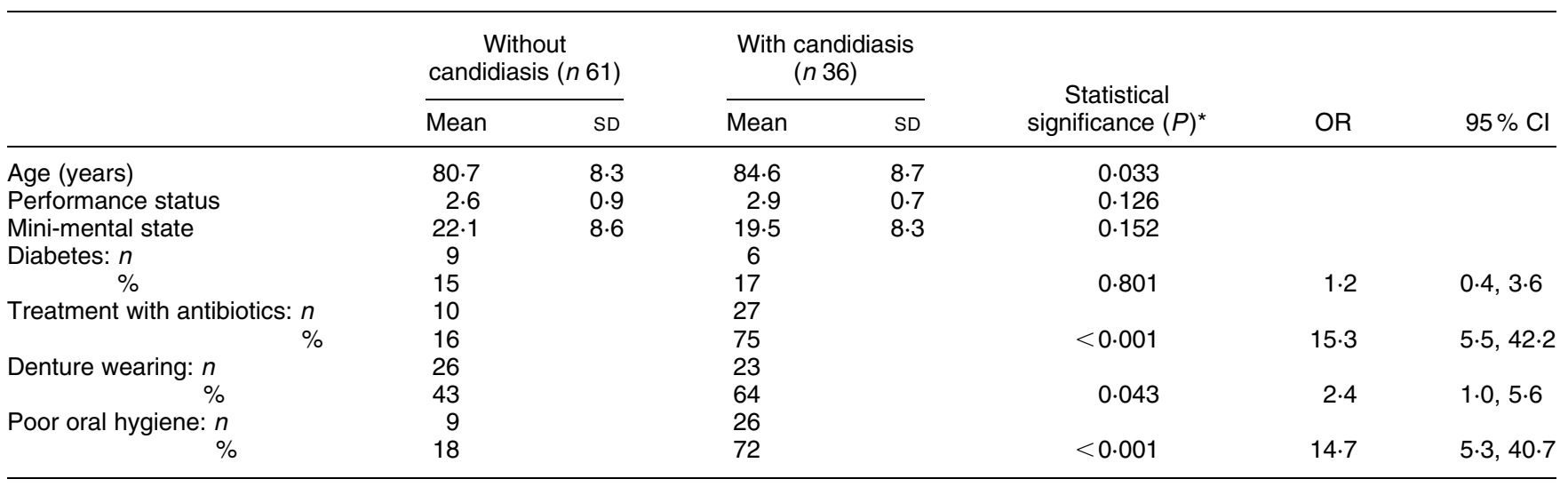

OR, odds ratio.

${ }^{*}$ Means between groups were compared using the unpaired Student's $t$ test; proportions between groups were compared using the $\chi^{2}$ analysis.

Table 6. Multivariate analysis of factors associated with the development of oral candidiasis

\begin{tabular}{lrll}
\hline & Odds ratio & $95 \% \mathrm{Cl}$ & $P$ \\
\hline Age & 1.2 & $1.0,1.3$ & 0.008 \\
Leg circumference & 1.2 & $0.9,1.4$ & 0.221 \\
Albumin & 1.3 & $1.0,1.7$ & 0.044 \\
Zn depletion* & 5.5 & $0.96,31.2$ & 0.056 \\
Vitamin C deficiency $\dagger$ & 33.8 & $1.8,624.3$ & 0.018 \\
Treatment with antibiotics & 110.7 & $9.0,1356 \cdot 7$ & 0.0002 \\
Denture wearing & 6.7 & $1.0,43.2$ & 0.046 \\
Poor oral hygiene & 45.5 & $5.3,389.6$ & 0.0005 \\
\hline
\end{tabular}

${ }^{*} \mathrm{Zn}$ depletion for values $<12.5 \mu \mathrm{mol} / \mathrm{l}$.

† Vitamin $\mathrm{C}$ values $<0.7 \mathrm{mg} / \mathrm{l}$.

The prevalence of undernutrition, as evaluated by BMI $<20 \mathrm{~kg} / \mathrm{m}^{2}$, was $32 \%$ in our population, which agrees with data reported in the literature. It was non-significantly higher in patients with candidiasis. However, our finding that patients with candidal disease had lower LC and serum nutritional protein levels suggests that protein-energy malnutrition may be involved in the colonisation and proliferation of the yeast in the mucosa. Moreover, oral candidiasis was associated with lower energy and protein intakes, which therefore may increase the risk of protein-energy malnutrition. This negative effect of the disease on intake could be reversed by successful treatment in our patients, as shown by improved intakes on day 30. On the other hand, the patients who did not recover from their candidiasis maintained an inadequate nutrient intake. Therefore, malnutrition and oral candidiasis appear interrelated; the former may facilitate the occurrence of the latter, but if undiagnosed, it may also result from it. Considering the whole population, about one-third of the patients had a daily intake below their estimated needs according to the Harris-Benedict equation. More striking was the observation that more than $93 \%$ of the population had a protein intake below the recommended value. The present findings underline the need for the continuous screening of oral intake, and for oral supplementation if necessary, in patients hospitalised in geriatric rehabilitation units.
We also observed a high prevalence of $\mathrm{Zn}$ depletion and vitamin $\mathrm{C}$ deficiency, both being two risk factors of oral candidiasis. One hypothesis to explain vitamin $\mathrm{C}$ depletion and deficiency is the difficulty for old individuals with bad oral health to eat fresh fruit and vegetables (Sheiham \& Steele, 2001). In addition, institutionalisation per se may render elderly individuals vulnerable to nutritional deficiency (Schorah et al. 1979; Marazzi et al. 1990). Some studies have pointed out that the storage of foods and the cooking procedures used in institutions may contribute to the loss of vitamins from the food. Moreover, acute disease could independently reduce ascorbic acid levels. Infectious diseases and the presence of an acute-phase response were reported as risk factors for vitamin $\mathrm{C}$ depletion (Fain et al. 2003). These findings are confirmed by a recent study (Long et al. 2003) which found extremely low plasma levels of ascorbic acid following trauma and infection. The return to normal plasma levels required supplementation with supraphysiological doses for several days in the early post-injury period. Although most of our patients were medically stable at the time of the study, they all came from acute medical care units or from orthopaedic hospitals and were not supplemented with vitamin $\mathrm{C}$.

One-third of our population had low serum Zn levels. The correlation of $\mathrm{Zn}$ levels with inflammatory proteins, together with abnormal values of these proteins in our population, suggests that the poor $\mathrm{Zn}$ status observed in some of our patients may be explained by a recent acute illness, as for vitamin $\mathrm{C}$ status. Moreover, this was not compensated by an adequate protein intake. Our finding that $\mathrm{Zn}$ depletion placed patients at an increased risk of candidiasis is in line with the recognised role of $\mathrm{Zn}$ in resistance to infection. A number of controlled trials have evaluated the potential benefits of supplementation programmes as a means of reducing the risk of infectious diseases (Baum et al. 2003; Black, 2003). Concerning Candida infections, Mocchegiani \& Muzzioli (2000) observed a complete disappearance of relapse of Candida aesophaga in patients infected with HIV. Another study from Ertekin et al. (2003) reported that infection with 
Candida species was prevented by $\mathrm{Zn}$ supplementation in patients receiving radiotherapy for head and neck cancer.

A low proportion of patients had Fe or folate depletion. However, it should be noted that more than $20 \%$ of our patient population had been $\mathrm{Fe}$ - and/or folate-supplemented before admission to our department. This indicates that in routine medical practice, more careful attention is given to $\mathrm{Fe}$ and folate-vitamin $\mathrm{B}_{12}$ status. In accordance with Jenkins et al. (1977) and Samaranayake \& MacFarlane (1981), we did not find an association of depletion in these elements with the development of candidal disease. However, differing data have been reported by others (Fletcher et al. 1975; Challacombe, 1986).

Other different host factors appeared independently implicated in the development of the disease itself; old age, treatment with antibiotics, denture wearing and neglected oral hygiene all predisposed to the occurrence of oral candidiasis. These findings are in accordance with several previous studies which also mentioned diabetes mellitus (Shay et al. 1997).

In conclusion, there is a high rate of oral candidiasis and malnutrition, in terms of protein-energy malnutrition and micronutrient deficiencies, in institutionalised elderly patients. This fungal disease appears to be associated with malnutrition and has a negative effect on energy intake, which subsequently may aggravate nutritional status. The present study needs to be consolidated by controlled randomised prospective studies with protein, $\mathrm{Zn}$, or vitamin $C$ supplementation to confirm the role of nutrition in the prevention of oral candidiasis. The present findings underline the importance of oral examination complemented by biological investigation and the need for extended protein, mineral and vitamin supplementation in this frail population.

\section{References}

Abbasi AA \& Rudman D (1993) Observations on the prevalence of protein-calorie undernutrition in VA nursing homes. $J \mathrm{Am}$ Geriatr Soc 41, 117-121.

Appollonio I, Carabellese C, Frattola A \& Trabucchi M (1997) Influence of dental status on dietary intake and survival in community-dwelling elderly subjects. Age Ageing 26, 445-456.

Baum MK, Campa A, Lai S, Lai H \& Page JB (2003) Zinc status in human immunodeficiency virus type 1 infection and illicit drug use. Clin Infect Dis 37, S117-S123.

Black RE (2003) Zinc deficiency, infectious disease and mortality in the developing world. $J$ Nutr 133, 1485S-1489S.

Blaum CS, Fries BE \& Fiatarone MA (1995) Factors associated with low body mass index and weight loss in nursing home residents. J Gerontol 50A, M162-M168.

Brocker P, Bourée P, De Rekeneire N, Maugourd MF, Perillat A \& Moulias R (2000) Prévalence des candidoses oropharyngées en gériatrie à propos d'une étude nationale multicentrique (A multicentre prevalence study of oropharyngeal candidiasis in geriatric patients). In L'Année Gérontologique 2000, pp. 133-150 Paris: Serdi Edition vol. 14.

Challacombe SJ (1986) Haematological abnormalities in oral lichen planus, candidiasis, leukoplakia and non-specific stomatitis. Int J Oral Maxillofac Surg 15, 72-80.

Challacombe SJ (1994) Immunologic aspects of oral candidiasis. Oral Surg Oral Med Oral Pathol 78, 202-210.
Dewys WD, Begg C, Lavin PT, et al. (1980) Prognostic effect of weight loss prior to chemotherapy in cancer patients. Eastern Cooperative Oncology Group. Am J Med 69, 491-497.

Ertekin MV, Uslu H, Karslioglu I, Ozbek E \& Ozbek A (2003) Effect of oral zinc supplementation on agents of oropharyngeal infection in patients receiving radiotherapy for head and neck cancer. J Int Med Res 31, 253-266.

Fain O, Paries J, Jacquart B, et al. (2003) Hypovitaminosis C in hospitalized patients. Eur J Int Med 14, 419-425.

Fidel PL (2002) Distinct protective host defenses against oral and vaginal candidiasis. J Med Mycol 40, 359-375.

Fletcher J, Mather J, Lewis MJ \& Whiting G (1975) Mouth lesions in iron-deficient anemia: relationship to Candida albicans in saliva and to impairment of lymphocyte transformation. $J$ Infect Dis 131, 44-50.

Folstein MF, Folstein SE \& McHugh PR (1975) 'Mini-mental state'. A practical method for grading the cognitive state of patients for the clinician. J Psychiatr Res 12, 189-198.

Jenkins WM, Macfarlane TW, Ferguson MM \& Mason DK (1977) Nutritional deficiency in oral candidosis. Int J Oral Surg 6, 204-210.

Lamy M, Mojon P, Kalykakis G, Legrand R \& Butz-Jorgensen E (1999) Oral status and nutrition in the institutionalized elderly. $J$ Dent 27, 443-448.

Lesourd B \& Mazari L (1999) Nutrition and immunity in the elderly. Proc Nutr Soc 58, 685-695.

Lode H \& Hoffken G (1989) Oral candidosis and its role in immunocompromised patients. Mycoses 32, 30-33.

Long CL, Maull KI, Krishnan RS, Laws HL, Geiger JW, Borghesi L, Franks W, Lawson TC \& Sauberlich HE (2003) Ascorbic acid dynamics in the seriously ill and injured. J Surg Res 109, 144-148.

Marazzi MC, Mancinelli S, Palombi L, Martinoli L, D’Alessandro de Luca E, Buonomo E \& Riccardi F (1990) Vitamin C and nutritional status of institutionalized and noninstitutionalized elderly women in Rome. Int J Vitam Nutr Res 60, 351-359.

Miller RA (1996) The aging immune system: primer and prospectus. Science 273, 70-74.

Mocchegiani E \& Muzzioli M (2000) Therapeutic application of zinc in human immunodeficiency virus against opportunistic infections. J Nutr 130, 1424S-1431S.

Mojon P, Budtz-Jorgensen E \& Rapin CH (1999) Relationship between oral health and nutrition in very old people. Age Ageing 28, 463-468.

Morley JE \& Kraenzle D (1994) Causes of weight loss in a community nursing home. J Am Geriatr Soc 42, 583-585.

Palmqvist S, Unell L \& Lindquist B (1984) Denture stomatitis in nursing home patients. Swed Dent J 8, 73-80.

Peterson DE (1992) Oral candidiasis. Clin Geriatr Med 8, 513-527.

Rothan-Tondeur M, Lancien E, Pialleport T, Meaume S, Moulias R, Marzais M, Cambau E \& Le Blanche AF (2001) Prevalence of oropharyngeal candidiasis in geriatric inpatients. $J \mathrm{Am}$ Geriatr Soc 49, 1741-1742.

Roza AM \& Shizgal HM (1984) The Harris Benedict equation reevaluated: resting energy requirements and the body cell mass. Am J Clin Nutr 40, 168-182.

Rudman D \& Feller AG (1989) Protein-calorie undernutrition in the nursing home. J Am Geriatr Soc 37, 173-183.

Samaranayake LP (1986) Nutritional factors and oral candidosis. J Oral Pathol 15, 61-65.

Samaranayake LP (1992) Oral mycoses in HIV infection. Oral Surg Oral Med Oral Pathol 73, 171-180.

Samaranayake LP \& MacFarlane TW (1981) A retrospective 
study of patients with recurrent chronic atrophic candidosis. Oral Surg Oral Med Oral Pathol 52, 150-153.

Samaranayake LP, Wilkieson CA, Lamey PJ \& MacFarlane TW (1995) Oral disease in the elderly in long-term hospital care. Oral Dis 1, 147-151.

Schorah CJ, Newill A, Scott DL \& Morgan DB (1979) Clinical effects of vitamin $\mathrm{C}$ in elderly inpatients with low blood-vitamin-C levels. Lancet $i$ 403-405.

Schou L, Wight C \& Cumming C (1987) Oral hygiene habits, denture plaque, presence of yeasts and stomatitis in institutionalised elderly in Lothian, Scotland. Community Dent Oral Epidemiol 15, 85-89.
Shay K, Truhlar MR \& Renner RP (1997) Oropharyngeal candidosis in the older patient. J Am Geriatr Soc 45, $863-870$.

Sheiham A (2001) Dietary effects on dental diseases. Public Health Nutr 4, 569-591.

Sheiham A \& Steele J (2001) Does the condition of the mouth and teeth affect the ability to eat certain foods, nutrient and dietary intake and nutritional status amongst older people? Public Health Nutr 4, 797-803.

Wilkieson C, Samaranayake LP, MacFarlane TW, Lamey PJ \& MacKenzie D (1991) Oral candidosis in the elderly in long term hospital care. J Oral Pathol Med 20, 13-16. 